\title{
The iPod Touch in association with other technologies in support of a community of inquiry in off-campus teacher education
}

\author{
Caroline Walta and Howard Nicholas \\ Faculty of Education, La Trobe University, Australia
}

\begin{abstract}
Hand-held technologies are pervasive and convenient in everyday use, but less commonly associated with the delivery of teacher education programs. This has implications for the way graduate teachers view the challenge of utilising these devices once they become classroom teachers, as pre-service teachers generally associate these devices with social rather than educational uses. However, as current learning theory research focuses on the importance of connected communities, the increasing take-up of online and blended learning programs brings with it an imperative to utilise technologies in ways which both support communities of inquiry and empower technology users to be creative. The paper explores the journey of a group of educators and members of a cohort of 65 pre-service teachers undertaking a one-year, graduate level pre-service teaching course in a blended learning environment managed from a regional campus of an Australian university. The learning environment is enabled through the iPod Touch and a range of other technologies. The use of the iPod Touch together with the associated technologies enabled both a Community of Inquiry to be established and improved familiarity with the potential for the iPod (or by extension the iPad) to enhance teaching in schools.
\end{abstract}

\section{Introduction}

This paper describes a study which involves pre-service teachers working in a blended/hybrid learning environment. The program is classified as blended/hybrid because some $75 \%$ of the experience is accessed online, which is within the $30-79 \%$ range of total course access identified by Allen \& Seaman (2003, p. 6). The study aims to explore the capacity for collaboration of iPod technology, in particular podcasting, in association with other technologies, namely the Blackboard Learning Management System (LMS), the virtual classroom Elluminate and a Mac OSX Server in establishing and supporting a Community of Inquiry (Garrison, 2011). It also explores the proposition that familiarity with working with technology will promote greater creativity and willingness to explore possibilities in a future classroom environment.

Despite the pervasiveness of hand-held technology in everyday use in our community, to date the majority of higher education institutions in Australia appear to have largely ignored this opportunity to encourage and support mobile learning on an institutional scale (Australasian Council on Open, Distance and E-learning [ACODE], 2011). Current research indicates that much of the focus of students' use of tools such as Facebook is social (Madge, Meek, Wellens, \& Hooley, 2009; Selwyn, 2009). In this paper we present evidence from a one-year, pre-service teacher education program that learning technologies embedded within mobile learning approaches can effectively create a Community of Inquiry even when face-to-face contact is limited. Reflecting assumptions similar to those of Andrews \& Tynan (2012), we argue that it is imperative that higher learning institutions structure teacher education programs in ways that students will experience how using these technologies can support the learning of others in the future. If teachers are also to be effective reflective practitioners, they need to develop not only the individual capacity to reflect, but also the capacity to work with colleagues as part of a wider community of inquiry (Garrison, Anderson, \& Archer, 2000).

\section{Background and context}

The Graduate Diploma in Education Middle Years program at La Trobe University is a one-year graduate-entry program through which students who have completed at least their first university degree can gain accreditation to teach across all sectors of school education in Victoria (P-12). The structures for learning are increasingly market-driven, reflecting student preference for ways of participating in the learning program while maintaining lifestyle, work and family commitments. Students entering this 
program anticipate that over the year, four weeks will be spent in activities in intensive face-to-face mode at the Shepparton Campus with the remainder of their academic studies (excluding the nine weeks of practicum) managed in an online environment.

From 2008, the program has been taught using a combination of face-to-face intensive workshops and various e-learning technologies, most notably the university's learning management system (then, Blackboard) and the virtual classroom software, named Elluminate at the time, to enable both synchronous and asynchronous interaction while students are not on the campus.

In the second half of 2009, special funding enabled the purchase of iPods and a server to support greater integration of mobile learning to complement the affordances of the other technologies. The funding supported both podcasting technology and the purchase of a pool of mobile devices so that every student in the program had access to an iPod Touch for that year - and other students had access to the same devices in ensuing years. The iPod initiative commenced in 2010.

The podcasting associated with a Mac OS X Server (henceforth, the server) provided pre-service teachers with opportunities to consider the potential for use of hand-held technologies for achieving learning outcomes and was also an alternative, flexible platform for generating, sourcing and accessing audio and multimedia material relevant to learning about teaching. This was a means of accessing and contributing to student exposure to current information and opinion exchange. This material was sourced from print and digital media comment on and research into educational issues. Reflection on this community and political debate around issues such as the introduction of the national curriculum or school rating websites was intended to supplement the fixed material in the LMS modules and to stimulate discussion during the weekly Elluminate tutorials.

The server was attached to the university system for the pilot study year. This enabled staff involved with the program to use Podcast Capture to generate and place podcast material onto the server. Students were then able to download this material to their iPods through an RSS feed or work directly from the server on their computers. The students were also able to create, post and access material to share via the server.

While the technologies that were introduced to the program have the potential to create high levels of sharing and interaction between students and staff, some evidence was required to establish whether a community of inquiry, as defined by Garrison (2011) was perceived by students. In this article, we explore some of the experiences of the staff and students as they negotiated working across the diverse technologies. The study was granted ethics clearance by the Ethics Committee of the university and participants gave informed consent.

McMillan and Chavis (1986, p. 9) draw four criteria of community (membership; influence; integration and fulfilment of needs; shared emotional connection) together as "a feeling that members have of belonging, a feeling that members matter to one another and to the group, and a shared faith that members' needs will be met through their commitment to be together" (McMillan \& Chavis, 1986). The diversity of student backgrounds, places of residence and professional practice, views of future employment contexts and locations as well as the relatively limited time that they and their lecturers spend "together" in the one physical space at the Shepparton Campus create a challenge to a number of assumptions about what might be required for a sense of community to be established. A further feature contributing to this diversity is that many students undertake this program while retaining diverse and demanding family and employment circumstances. As a result, the program creates a highly relevant context for the exploration of the potential for the development of a community of inquiry.

\section{The role of podcasting}

Research before 2006 tended to focus on the issue of podcasting as a substitute for face-to-face lecturing and whether this is appropriate in terms of student rights and student learning (Heileson, 2010, p. 2). Later research, which is informed by the evolution of podcasting from audio to multimedia production with the advent of more sophisticated hand-held devices, focuses more on instances where podcasting has become part of the overall design of a learning program, utilizing its potential to offer a range of learning opportunities in association with the learning outcomes and other technological tools in the program (Draper \& Hitchcock, 2006; Edirisingha, Salmon, \& Fothergill, 2006; Evans, 2008; Lee \& Chan, 2007a, 
2007b; Lonn \& Teasley, 2009; Ragusa, Chan \& Crampton, 2009). Podcasting that allows students to coconstruct knowledge and to contribute to the learning of the group has been reported in some research (Chan, Lee \& McLoughlin, 2006; Dale \& Pymm, 2009; Frydenberg, 2006; McGarr, 2009).

Edirisingha et al. (2006), in a study in the UK, proposed a concept that they call Profcasting. They reported that that podcasting used in this way was supportive of student learning, especially in areas of organization, enabling depth of learning, bringing about positive relationships in an online environment and ease of mobile access. However, learners who were listening to the podcast needed support and podcasting needed to be integrated into existing course material, strongly linked to other collaborative learning that was fresh and relevant, reusable and downloadable.

Podcasting as a learning tool has been heralded from its earliest appearance as a potentially cost effective, readily accessible and potentially motivating tool for learning (Draper, 2007). McGarr (2009) noted that research into podcasting in higher education highlights three main uses, namely supplementary, where the material associated with a lecture is provided; complementary, where material which supports or enriches the lecture is provided, and creative, where use of podcasting is part of knowledge creation and sharing by students (pp. 310-313). Heileson (2010) comments on podcasting for classroom teaching (p. 1). In the latter category he distinguishes substitutional use (where podcasting is taking the place of the classroom teaching), supplementary use, described as providing summaries and additional materials and creative use - production by learners (p. 1).

In line with the philosophical underpinning of the program, where content material was constructed through dialogue and access to competing sources of knowledge, use of podcasting for supplementary and creative uses, as defined by McGarr, was part of embedding podcasting into the program. McGarr (2009) summarises the issues:

While podcasting has the potential to enhance the students' learning experience, it can also reinforce the worst aspect of the transmission model of learning. For this reason, future use of these technologies should be learner led, rather than technology led... Future uses of the technology should be guided by sound educational goals that aim to improve the students' existing experience, rather than being guided by vague claims of revolutionizing it (p. 319).

\section{Theoretical issues in program design}

Learning theory informs curriculum design, but learning theory is highly dynamic. According to Mayes and de Freitas (2007, Appendix 1), learning is no longer a "series of competing accounts", but understood broadly as 1) associative: Building concepts or competencies step by step; 2) constructive-individual: Achieving understanding through active discovery; 3) constructive-social: Achieving understanding through dialogue and collaboration; and 4) situative: Developing practices in a particular community that exist in relation to one another. Mayes and de Freitas (2007) note that all perspectives emphasize the importance of activity for the learner, the integration of learning within the activity and constructive alignment of activities, outcomes and assessment criteria. Mediating these dimensions is a responsibility of the course organizer, but within a broadly constructivist approach, such mediation has to involve the learners - the pre-service teachers, which involves a view of participants as members of some kind of community.

Furthermore, program design, which features technology in its operation, is informed by notions of elearning and m-learning that place the emphasis on the potential for technology to support learning within what has already been identified as a constructivist paradigm rather than assuming a new paradigm.

$\ldots$ in the powerful new learning opportunities that are being facilitated in an entirely new way through the internet we are witness to a new model of education, rather than a new model of learning (Mayes \& de Freitas, 2007; p. 14)

The importance of program design that aligns outcomes with learning activities supported by technology is a common theme in current literature (Beetham \& Sharpe, 2007; Biggs \& Tang, 2009; Oliver, 1999; Salmon \& Edirisingha, 2008; Stephenson, 2001). Other research has documented the effective use of technological tools, especially the collaborative functions of LMSs, to facilitate communication and 
interaction between students in programs and courses (Garrison \& Kanuka, 2004; King, 2002; Rovai, 2002). More recent research features the use of mobile technology, especially associated with use of podcasting as a feature of program design (Dale \& Pymm, 2009; Edirisingha et al., 2006; Lee \& Chan, 2007a, 2007b; McLoughlin \& Lee, 2008). This line of research highlights a shift from focusing on the interactivity of the web 2.0 tools themselves to an environment where learning is more truly created and shared by all participants.

The expanding range of web 2.0 applications (podcasts, weblogs, wikis etc.) increases support for learners as active participants, creators of knowledge and seekers of engaging personal experiences (McLoughlin \& Lee, 2008, p. 10). These authors point to the need to

expand our vision of pedagogy so that learners become active participants and co-producers rather than passive consumers of content, and learning processes are participatory and social, supportive of personal life goals and needs.

In this article, we demonstrate how in the blended/hybrid learning environment of this program various elements of the teaching presence component of the model led to the creation of a Community of Inquiry. Garrison (2011) focuses on the integration of technology into the creation of community in consideration of the design and organization, facilitation and direct instruction as key roles for the teacher - in this case, the course organisers. For this reason we have used this model to explore concepts of the establishment of a technology enabled community of enquiry.

Garrison (2011, p. 23) proposed the following elements and relationships within a Community of Inquiry $(\mathrm{CoI})$ :

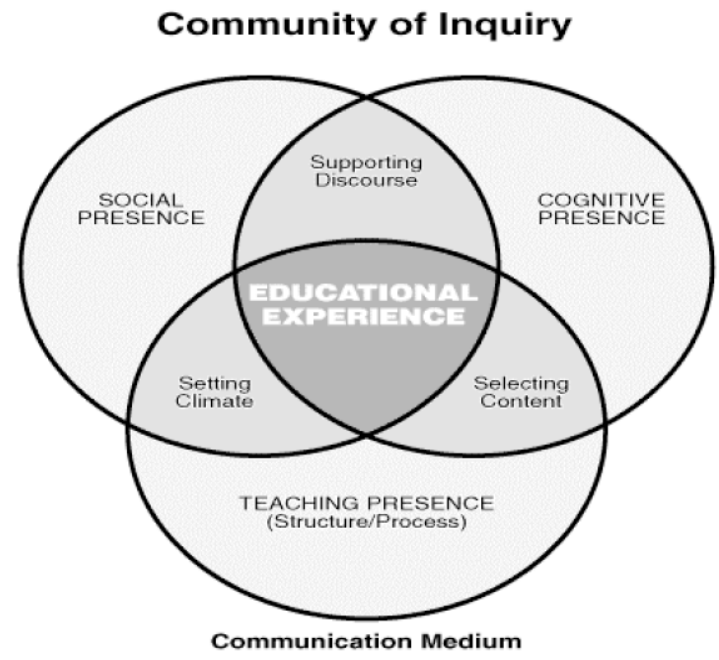

Figure 1. Community of Inquiry model.

For the sake of consistency and clarity, we present Garrison's original definitions of the elements of the CoI model. For Garrison (2011, p. 30) social presence reflects and promotes social interaction that creates a sense of belonging and facilitates collaborative learning. Garrison (2011, p. 127) argues that social presence is an important contributing element in learning and interaction through its three elements of interpersonal communication, open communication and cohesive communication (Garrison, 2011, pp. 3839). Cognitive presence is "the intellectual environment that supports sustained critical discourse and higher order knowledge acquisition and application." (p. 42). Teaching presence involves "shaping the appropriate transactional balance and, along with the learners, managing and monitoring the achievement of worthwhile learning outcomes in a timely manner. ... [It] performs an essential service in identifying relevant societal knowledge, designing experiences that will facilitate reflection and discourse and diagnosing and assessing learning outcomes." (pp. 54-55). The technology is, therefore, not an discrete element added on to other elements of the program, but rather a flexible resource that supports diverse 
educational activities and various kinds of educative relationships between participants, as indicated in the next section.

\section{The course elements in relation to Garrison's Col model}

The table below presents an overview of the nature of participation in the program and the allied technology tools. As indicated earlier, an important component of the program was the inclusion of five weeks of face-to-face learning over three blocks. This serves two functions, one of which is social and the other of which is content-based. King (2002) has demonstrated that students collaborate more effectively in an online environment if they have had opportunities to meet face-to-face to build relationships. In addition, we considered that some aspects of learning about teaching e.g., role-play for student management and participation in games and activities associated with method teaching in schools are considered to be currently better experienced in a face-to-face environment. This may change as technologies evolve and social media allow for more casual interaction. The evolving potential of mobile learning, and in particular podcasting, has recently influenced the structure and design of the program as we strive to expose teachers of the future to the potential for technology to support and enhance learning in even more flexible and accessible ways.

The following table also links the use of elements of a Community of Inquiry to technological tools which support elements of social presence and cognitive presence, both of which are linked to connectedness and learning. These elements become the means by which teacher presence promotes discourse and critical enquiry.

Table 1

Relations between elements of Community of Inquiry and technologies

\begin{tabular}{|c|c|c|}
\hline $\begin{array}{l}\text { Elements in the } \\
\text { Community of Inquiry }\end{array}$ & Online activity & $\begin{array}{l}\text { Technological } \\
\text { Tool/Online learning } \\
\text { system }\end{array}$ \\
\hline Social Presence & $\begin{array}{l}\text { LMS Discussion spaces: server- personal } \\
\text { wikis }\end{array}$ & $\begin{array}{l}\text { Learning Management } \\
\text { System - Blackboard }\end{array}$ \\
\hline Interpersonal & $\begin{array}{l}\text { Practicum blogs - associated with seeking } \\
\text { help and sharing experiences }\end{array}$ & Elluminate \\
\hline Open communication & $\begin{array}{l}\text { Elluminate - associated with small group } \\
\text { use } \\
\text { Skype - associated with iPod use } \\
\text { Elluminate for tutorial small group } \\
\text { discussions }\end{array}$ & $\begin{array}{l}\text { Skype } \\
\text { iPod Touch }\end{array}$ \\
\hline Cognitive Presence & Assessment tasks & LMS \\
\hline $\begin{array}{l}\text { Facilitating reflection } \\
\text { and discourse } \\
\text { Higher Order Thinking }\end{array}$ & $\begin{array}{l}\text { Reflective and critical inquiry associated } \\
\text { with selected learning material- use of } \\
\text { collaborative spaces in LMS and Server } \\
\text { Elluminate tutorials }\end{array}$ & $\begin{array}{l}\text { Server } \\
\text { Elluminate }\end{array}$ \\
\hline $\begin{array}{l}\text { Teacher presence } \\
\text { Shaping the learning } \\
\text { experience to promote } \\
\text { reflection and discourse } \\
\text { Collaboration with } \\
\text { learners to achieve } \\
\text { learning outcomes }\end{array}$ & $\begin{array}{l}\text { Podcasting as part of design to promote } \\
\text { shared learning and support discourse; } \\
\text { Podcasting in response to assessment } \\
\text { tasks; used to generate audio files of } \\
\text { interviews for posting and tutorial } \\
\text { discussion; students source and share } \\
\text { online podcasts and other resources }\end{array}$ & $\begin{array}{l}\text { iPod Touch associated } \\
\text { with Server }\end{array}$ \\
\hline
\end{tabular}

Further expanding on information contained within the table, activities in the program reflect a focus on collaboration, authentic learning experiences and higher order thinking, especially involving reflection on learning, including:

- Sharing observations of classroom approaches to pedagogies and management through open discussions in the LMS and via the server 
- Building a portfolio of evidence of learning, including links to resources and software using designated software using PebblePad

- Creating units of work through collaboration and sharing online using the LMS

- Creating multimedia podcasts which simulate student learning activities associated with learning about literacy using the iPod Touch

- Creating multimedia podcasts which are themselves learning objects accompanied by audio podcasts about their use in teaching using the iPod Touch

- Participation in supportive blogging during practicum using both the LMS and the server

- Evaluation of software for educational use in a shared environment

- Opportunities to present and discuss components of a developing philosophy of education with lecturers and other colleagues using an interactive online module featuring shared discussion/journal spaces

- Responding reflectively to online readings and other sourced material in the LMS

- Engaging in peer-to-peer review of teaching where physical location allows for this

- Supporting others though tutorial blogs during practicum using both the LMS and the server.

In support of our argument that these uses of new technologies do not create a new paradigm of learning, we show below that the above practices reflect well-established principles of professional learning. Practices adopted in the program are aligned with the seven fundamental principles for teacher education programs and practices outlined by Korthagen, Loughran, and Russell (2006).

In the following table, teacher education elements (Korthagen, Loughran, \& Russell, 2006, pp. 10251036) are matched with the technology in the program that supports them:

Table 2

Relations between elements of teacher education and technologies

\begin{tabular}{|c|c|}
\hline Learning context & Technology \\
\hline $\begin{array}{l}\text { Shared participation and } \\
\text { interaction }\end{array}$ & $\begin{array}{l}\text { Elluminate for tutorials; wiki space for podcasting; student blogs; } \\
\text { public posting of assessment }\end{array}$ \\
\hline Opportunities for reflection & $\begin{array}{l}\text { Reflective journals in the LMS; tasks associated with practicum e.g. } \\
\text { reflecting on self-administered audio and student feedback }\end{array}$ \\
\hline Opportunities for collaboration & $\begin{array}{l}\text { Joint participation in assessment utilizing online technologies for } \\
\text { collaboration; use of Elluminate }\end{array}$ \\
\hline $\begin{array}{l}\text { Opportunities to receive/respond to } \\
\text { feedback/ } \\
\text { scaffolding learning }\end{array}$ & $\begin{array}{l}\text { Structure of assessment tasks in the LMS; use of designated blogs; } \\
\text { public sharing of assessment in the LMS and on Wiki spaces }\end{array}$ \\
\hline $\begin{array}{l}\text { Opportunities to learn about and } \\
\text { through technologies }\end{array}$ & $\begin{array}{l}\text { Some autonomy associated with assessment; public sharing; } \\
\text { community of learners enabled to assist in an online environment }\end{array}$ \\
\hline $\begin{array}{l}\text { Engagement with authentic } \\
\text { curriculum through structure of the }\end{array}$ & $\begin{array}{l}\text { All assessment tasks were learning activities designed for learning } \\
\text { about teaching and modelling approaches for future classroom use- }\end{array}$ \\
\hline learning modules, podcasting and & e.g., creating podcasts; digital stories associated with critical \\
\hline the nature of assessment items & $\begin{array}{l}\text { literacy development in schools, evaluating the potential for use of } \\
\text { a range of technologies in student learning }\end{array}$ \\
\hline $\begin{array}{l}\text { Opportunities to be knowledge } \\
\text { creators }\end{array}$ & $\begin{array}{l}\text { Use of podcasting - both created and sourced placed in wiki space } \\
\text { for discussion or written comment }\end{array}$ \\
\hline $\begin{array}{l}\text { Opportunities to form communities } \\
\text { of learners in a virtual environment }\end{array}$ & $\begin{array}{l}\text { Use of virtual tutorial groups associated with podcasting, meeting } \\
\text { regularly in Elluminate with associated reciprocal peer review in } \\
\text { practicum placement }\end{array}$ \\
\hline
\end{tabular}

The process of use by and feedback from students had an impact on the quality and use of podcasting and the server throughout the year of the pilot study. We attempted to ensure that the material presented was not one-way knowledge delivery. Students were directed to listen to certain material, often containing conflicting opinions and approaches, and to consider certain questions for discussion in their online tutorial that week. Other early initiatives included directing students to gather data themselves and post it on the server for others to consider. This data often took the form of recorded interviews and links to podcasts from YouTube, EdPod and other sources accessed by students at their own initiative. 
During the face-to-face intensive component, students attended workshops run by two teachers from schools that featured iPod use in personalized learning programs. These workshops enabled students to become more familiar with educational applications (apps) for the iPods and with their potential within educational programs in schools. A blog was set up in LMS Blackboard in which students could share ideas for other educational apps and to work with one another to solve any technical or technological issues that they encountered with the devices.

\section{Method}

Our interest in this topic was motivated by information obtained from the cohort of 60 students in their course evaluation in the year prior to the iPod initiative. These students affirmed that they had developed a strong sense of community in an iteration of the course that was also hybrid/blended learning, but did not use mobile devices. The earlier course utilized Elluminate for online lecture delivery, a structure that was replaced by iPods and Elluminate tutorials. Data about the sense of community with the previous year's cohort makes clear that nearly two-thirds of the students from that year of the program $(62.5 \%)$ felt the need for connection. And further, $80 \%$ of them felt a sense of being connected most or all of the time. It was therefore imperative that the iPod initiative did not threaten a sense of connectedness which had been demonstrated to be well established through the existing structure.

This article is based on responses from members of a cohort of 65 students enrolled in the pre-service program in the first year of the iPod initiative. We used online surveys via Survey Monkey that were made accessible (anonymously) to all students, supplemented by interviews with volunteer students and two volunteer members of staff. In total 36 students responded to the survey and 12 volunteered to take part in the group interviews. The responses from all volunteers were accessed in the collation and interpretation of the data.

We cannot precisely quantify the variation in pre-existing technological skills among the students because this was not included in the survey due to the focus being on a change of position, regardless of starting point. However, responses to survey items related to confidence in using the technologies (see Results) together with our impressions gained from student participation in and comments during the initial familiarization activities would suggest that about 15 of the total cohort of 65 could be regarded as unfamiliar and uncomfortable with key forms of digital technologies when they began the program. A similar-sized group could be regarded as sophisticated and confident users of digital and mobile technologies. We could not detect any consistent associations with age or gender in the distribution of these capacities.

Data about the impact on learning of the iPod initiative was gathered progressively throughout the course through blogs in the LMS and the server and through an initial and final survey of students. The blog was optional and contained entries initiated by 13 different students, all of which received replies from others enrolled in the program.

A survey midway through the year was followed by focus groups with volunteer students. The survey consisted of 24 questions, the last of which was open and invited students to comment on the experience of iPod technology during the course and gave an opportunity to offer advice on how to improve the experience. There was a $74 \%$ response to the survey with half of those students offering further data through the open question. Responses to the mid-year survey informed our design of the subsequent survey upon which this article is based, the exit survey.

The final exit survey included a number of places where students indicated their evaluation of the role of the iPod initiative in their learning. We received 36 responses to this survey ( $55 \%$ of the cohort). In citing data related to the changes in perspective for the course participants, we use this exit survey as the data. The focus groups were also asked to expand on their experiences of the overall initiative. Comments and quotes from the students are presented without attribution to preserve anonymity. All quotes come from different students either in interviews, blog/wiki contributions or in comments on the various surveys and requests for formal evaluations of their experiences. 
We adopted an emergent case study approach with the survey as the first part and the group-based interviews subsequent to the survey, using self-nominated volunteers in that survey. We sought to understand the experiences and perceptions of the program participants in context. In the interviews we endeavoured to pursue the issues that they had raised in their responses to the online survey. We did not identify any patterned relationship with initial confidence/capacities in willingness to volunteer to be interviewed. Nevertheless, in the formation of the groups for interview we sought to bring together a variety of both initial positions and experiences of the course. All interviews were audio-recorded and transcribed for meaning, prior to analysis.

\section{Results}

Some students found the initial workshops associated with accessing the server and general functioning of the iPods difficult to follow, as they had not previously engaged with a server or accessed material on an iPod. Once the course was underway, students with more advanced technical understanding began to collaborate with and respond to their less experienced peers when those peers experienced difficulties. This was an early example of the value of shared collaboration in the co-construction of knowledge and was to be a strong feature of the overall positive regard with which students ultimately held the initiative - we view it as evidence of initial moves toward a community.

As students and staff became more familiar with the design options associated with podcasting and the capacity of the server to allow the sharing of learning objects, further uses were trialled. A number of Semester 2 assessment items involving use of technology were changed to reflect the capacity of the server to host multimedia files from both staff and students. These included students creating an educational app which targeted an aspect of numeracy or literacy and producing a digital story suitable for a middle year's literacy task. Staff and students also set up communication blogs for students during their teaching practicum placements. The space enabled students to post audio files of their own teaching, images of student work and other material with reflective comments.

As discussed, the iPod Touch initiative had two broad aims: familiarising students with hand-held technologies in order that they might have opportunities to consider their application to future school learning, and enabling learning through a technologically managed environment which further supported a community of inquiry.

As indicated, the concept of a Community of Inquiry links three broad areas, namely, Social Presence, Cognitive Presence and Teaching Presence. These three components interlink to become the total educational experience (Garrison, 2011, p. 23). The data associated with the iPod initiative is considered within the theoretical framework of the CoI model.

Issues of community and connectedness had been explored using survey data in the year prior to the introduction of the iPod Touch. An exit survey for evaluation purposes was completed by $80 \%$ of students in the previous course, when iPods had not been used. The findings were as follows:

During participation in the program how often did you feel the need be connected to a learning community?

Table 3

Need for connection with a community

\begin{tabular}{ll} 
Not at all & $2.5 \%$ \\
A little of the time & $35.0 \%$ \\
Most of the time & $55.0 \%$ \\
All of the time & $7.5 \%$ \\
\hline
\end{tabular}


To what extent did you feel a sense of being connected in a learning community?

Table 4

Need for connection with a community

Not at all $2.5 \%$

A little of the time $\quad 35.0 \%$

Most of the time $\quad 55.0 \%$

All of the time $\quad 7.5 \%$

The initial blog completed by the students after the introduction of the iPods demonstrated the evolving learning of students in a shared journey. Most entries indicated excitement but also some confusion about expectations of the iPods. These entries also contained moderating voices from those whose technological journeys were more advanced, as well as pointers to useful websites and apps. This initial shared space fits with Garrison's (2011) description of interpersonal social presence as students used the space to communicate their reactions to the new technology, to question its potential and to reassure each other, e.g.,

\section{Dear [NAME]}

I was a bit like you, I tend to use my laptop and phone for most things. BUT I have started to use my iPod as a one on one teaching tool. I have recorded story books for a Grade 1 student, he enjoyed listening at the same time followed the print and pictures. This adds another dimension to his learning, he is intellectually disabled. I have down loaded a metric conversion app, atlas app and dictionary app; again I use these for one on one teaching, mainly for a Grade 5 student who has learning issues. It appears to me regardless of learning abilities, technology - gadgets really- attract the attention of students, they are not afraid to touch, click, drag. I am hoping to use the ipod during practicum.. I'll let you know the progress I make - stay positive.

The next two tables clearly show the growth in confidence from before the program commenced to its conclusion. Prior to the program, only $54.2 \%$ of the 36 students who responded in the final survey had been confident about using the iPods, and $28 \%$ felt a strong lack of confidence. However, by the end of the program, the level of overall positive confidence was $86.5 \%$, with the major shift being from (strong) disagreement to some form of agreement.

I was confident about using the iPods before I started the course

Table 5

Confidence prior to the course

\begin{tabular}{ll}
\hline Strongly disagree & $28.0 \%$ \\
Disagree & $13.6 \%$ \\
Slightly disagree & $3.4 \%$ \\
Slightly agree & $16.9 \%$ \\
Agree & $25.45 \%$ \\
Strongly agree & $11.9 \%$ \\
\hline
\end{tabular}


I feel confident that I could use iPods in my own teaching in schools if the school had a set

Table 6

Confidence at the end of the course

\begin{tabular}{ll}
\hline Strongly disagree & $1.7 \%$ \\
Disagree & $5.1 \%$ \\
Slightly disagree & $6.8 \%$ \\
Slightly agree & $28.8 \%$ \\
Agree & $47.5 \%$ \\
Strongly agree & $10.2 \%$ \\
\hline
\end{tabular}

At the time of leaving the program, $86.5 \%$ of the 36 responses agreed that they were confident enough to use iPods in their teaching. This is additionally reflected in other measures of actual use.

I am very thankful that I could expand my knowledge with the use of ICT in this course .... Without this privilege [use of iPods], I would feel slightly pressured. .. I have recently purchased an iPad as I am inspired to further my studies to [provide] a better learning experience for my future students in primary. [Student comment]

Although students expressed regret about not having sets of the devices to enable them to teach with iPods on practicum, several students used their own iPods to enable individual and shared activities (use of the dictionary; taking the iPod home and writing in a group journal) while one student encouraged her students to bring hand-held devices from their homes and set up a literacy task (which subsequently appeared in the local paper under the heading "iPod Class - kids use latest technology to learn").

Students appreciated the flexibility of having podcasts on their iPods as they used them to listen at times and in places of convenience (Dale \& Pymm, 2009; Draper, 2007; Tynan \& Colbran, 2006;).

I appreciate the flexibility of material delivered through podcasting

Table 7

Appreciation of flexibility

\begin{tabular}{ll}
\hline Strongly disagree & $0 \%$ \\
Disagree & $1.7 \%$ \\
Slightly disagree & $1.7 \%$ \\
Slightly agree & $25.4 \%$ \\
Agree & $50.8 \%$ \\
Strongly Agree & $20.3 \%$ \\
\hline
\end{tabular}

We also sought feedback on the use of podcasting as a replacement for the Elluminate "lectures" (as opposed to the Elluminate used for student interactions with lecturers in so-called tutorials). Through Elluminate it is possible to present relevant, self-generated learning material in real or asynchronous mode, using the computer for access. The survey feedback on this was confusing and needed to be clarified in a later focus group. 
I would prefer Elluminate lectures to podcast tutorials

Table 8

Preference for elluminate or podcast experience

\begin{tabular}{ll}
\hline Strongly disagree & $10.2 \%$ \\
Disagree & $16.9 \%$ \\
Slightly disagree & $15.3 \%$ \\
Slightly agree & $16.9 \%$ \\
Agree & $28.8 \%$ \\
Strongly Agree & $11.9 \%$ \\
\hline
\end{tabular}

The above shows a slight preference for use of Elluminate over podcasting for "lectures". However, the negative dimensions of this response can be more clearly understood by reference to the next survey item. Students to some extent still differentiate the concept of a lecture (a longer exposure to information) from a podcast, where information is succinct and readily re-accessed.

The podcasts are an effective environment for presenting new material in this course

Table 9

Are podcasts effective?

\begin{tabular}{ll}
\hline Strongly disagree & $1.7 \%$ \\
Disagree & $5.1 \%$ \\
Slightly disagree & $1.7 \%$ \\
Slightly agree & $30.5 \%$ \\
Agree & $52.5 \%$ \\
Strongly Agree & $8.5 \%$ \\
\hline
\end{tabular}

In contrast to the first set of responses, the responses in Table 9 show a strong affirmation of the use of podcasting for presenting new material, a function normally associated with "lectures". Students in the focus group indicated that a great deal depended on the nature of the material or the purpose for which podcasting was used.

I have enjoyed receiving lectures as podcasts, more of these during practicums would be beneficial as it's easy to feel isolated at these times. Having that extra reinforcement, refocus, reminders etc. would help a lot. [Student comment]

Some students indicated a preference to access podcasts from their computers if they involved visual as well as audio material since the iPod screen was very small. A subsequent focus group clarified that the overall value of the podcast, when delivering learning material, was its flexibility, convenience and the way it enabled the listener to slow down or speed up the delivery of the content.

I think the use of iPods is fantastic and puts the course into a relevant context for teaching this generation of students. I would recommend more of the 'intensive' sessions are also placed into podcast so we can refer back to them; particularly as we prepare of philosophy statements. Sometimes it is nice to be able to go back over a lecture or tutorial as the topic becomes applicable to a task you are involved with. I personally found the iPod a fantastic tool not only for teaching students, but also so I could manage the load of this course. As a busy mum, with work commitments and family commitments, the iPod has allowed me to listen (and sometime re-listen) to lectures, podcasts etc. while driving, watching the kids playing basketball, and the list goes on. The fact that you can have it in your bag, for use anytime, anyplace use, is extremely practical (unlike your computer or an $\mathrm{iPad}$ ). [Student comment] 
Students therefore did not fully concur with McGarr (2009, p. 319), who cautions against the use of podcasting for providing lectures, summaries or syntheses of course material in the manner of the "worst aspects of the transmission model". However, podcasting in this program was never entirely a one-way transmission. All podcasts contained follow up ideas for personal research and transmission, critical evaluation and reflective discussion, either during the weekly online tutorials or via the server in the open discussion spaces. Further, the combination of the podcast with the mobile device meant that the students were able to control when and how they accessed the podcast.

Consistent with the multidirectional framing of the course as a whole, students commenced accessing and disseminating sourced and generated podcasts and other multimedia as resources, which they shared through the server. The use of podcasting in this way conforms with notions of both Social, Cognitive and Teacher Presence in a Community of Inquiry (Garrison, 2011). Students had opportunities to share in knowledge construction and dissemination through podcasting and accessing multimedia software (features of Teacher Presence); students were able to critically reflect on and engage in discourse about a range of material (Cognitive Presence) and were able to engage with open communication in relationships of trust and shared learning (Social Presence).

Data from the open comments and focus groups support the above claims. Students were positive about the value of making and listening to a range of short audio products.

I have found this ... to be extremely beneficial in critiquing my own teaching style to date. This will definitely be a method of reflection I will continue to use in my future teaching. [Student comment]

The last thing that I picked up from the audio recording ... was that when asking questions I don't provide long enough wait time. When I'm teaching, I think that I'm giving them enough time to respond however in the recording it doesn't seem that long at all. What's more, now that I think about it, there is usually the same few students who are contributing to the discussions. [Student comment]

Students indicated that interviews with educational writers, which formed the subject of two podcasts, helped to scaffold learning associated with reading material.

I found it really useful to listen to you asking questions and interrogating the speaker. It helped me to understand the ideas in the articles more clearly. [Student comment]

In focus groups students suggested using podcasts to provide key ideas or generate questions and thereby scaffold readings associated with the learning modules in the LMS. In the focus group discussion following the survey two students indicated that ALL podcast material which dealt with knowledge delivery was probably better delivered through an interview format, that is, having a second person interact and ask questions or comment was better for listening and learning than listening to a monologue. The presentation of podcast material as dialogue rather than monologue clearly represents an additional element of interaction, which may support the learning of the listener. This is consistent with the findings of Edirisingha et al. (2006).

Other ways to consider podcasting, as it became embedded in the learning assessment tasks in Semester 2, are supported by more recent research (McLoughlin \& Lee, 2008), which supports the concept of learning design reflecting an understanding of the importance of establishing a Community of Inquiry. Overall, podcasting contributed to opportunities for students to access, generate, collaborate, reflect and share ideas about learning and teaching. Podcasting was a means by which students collaborated to produce learning materials, which were accessed and critiqued by others. The podcasts were associated with both fixed readings in modules and with other sources accessed for the purposes of generating discussion. Podcasting as a means of expressing understanding through multimedia was a format for communicating work tasks (assessment items) as part of a shared platform for learning. In the process students experienced structuring similar opportunities for the students of the future.

Overall the experience of podcasting within the program has demonstrated the capacities for technological tools to be adapted to support learning in line with learning theories and learning design. As 
in the example of the student who encouraged her own students to bring mobile devices from home, the students were motivated to use the technology and consider its application to future school contexts. The use of podcasting in the program achieved positive outcomes for learning associated with both the original intentions and in fact exceeded the expectations of the course designers.

I didn't think as many students would have the capacity to go from being cautious to being regular users of ICT and applying it to uses in schools. When we started out, I didn't know how far we could take it. [Course designer]

When asked to reflect on reasons for selecting the course in $2010,77.4 \%$ of the students who responded to the exit survey selected reasons associated with the online nature of participation. The majority identified with the flexibility to support their lifestyle needs that the use of blended learning enabled. Students were asked to rate aspects of the program in terms of how helpful they had been in supporting their learning. All components of the program were rated from moderately (podcasts) to extremely helpful (practicum and field work; working with a designated tutor is a virtual tutorial group). 93.3\% of students identified use of technology within the overall design of the course as either very helpful or extremely helpful, which was almost the same as the response to participation in the intensive face-to-face component.

Students were asked to identify those features of the program that had had a positive impact on their learning (not at all; minimally; moderately; strongly; very strongly). As shown in Table 10, the largest proportion of student respondents identified very strongly with:

- The collaborative learning environment facilitated by technology

- The flexibility enabled by the online structure

Table 10

Strongly supportive elements of the program

\begin{tabular}{llllll}
\hline Identification & Not at all & Minimally & Moderately & Strongly & Very strongly \\
\hline $\begin{array}{l}\text { Collaborative learning } \\
\text { environment }(n=35)\end{array}$ & 0 & 0 & $28.6 \%$ & $28.6 \%$ & $42.9 \%$ \\
$\begin{array}{l}\text { Flexibility of online structure } \\
(n=36)\end{array}$ & $2.8 \%$ & 0 & $13.9 \%$ & $25 \%$ & $58.3 \%$ \\
\hline
\end{tabular}

As shown in Table 11, the largest proportion of the 36 student respondents identified strongly with:

- The support of fellow students

- The assistance and support of staff

- The relevance of the program to future teaching

- The richness of material associated with learning about teaching in the program.

Table 11

Strongly supportive elements of the program $(N=35)$

\begin{tabular}{lccccc}
\hline Identification & Not at all & Minimally & Moderately & Strongly & Very strongly \\
Support of fellow students & 0 & $2.9 \%$ & $20 \%$ & $40 \%$ & $37.1 \%$ \\
Assistance and support of staff & $2.9 \%$ & $2.9 \%$ & $14.3 \%$ & $48.6 \%$ & $31.4 \%$ \\
Relevance to future teaching & 0 & $2.9 \%$ & $2.9 \%$ & $51.4 \%$ & $42.9 \%$ \\
Richness of material & $2.9 \%$ & 0 & $2.9 \%$ & $57.1 \%$ & $37.1 \%$ \\
\hline
\end{tabular}

We consider these findings in terms of their compatibility with Garrison's (2011) Community of Inquiry. Under Social Presence could be placed the support of fellow students, the flexibility enabled by the online structure and the assistance and support of staff. Under Cognitive Presence could be located the relevance of the program to future teaching and the richness of material associated with learning about teaching in the program. Teacher Presence, which is the utilization of the above to design learning environments that 
support critical reflection and life time learning, combines the collaborative learning environment facilitated by technology, the richness of material and the support of staff.

Reflecting on this high level of student satisfaction with their learning, the richness of the learning experience seems to relate to the capacity of the program to flexibly incorporate a range of material of interest and relevance to learning about teaching and to allow students to become active partners in the knowledge generation through engagement in a Community of Inquiry.

The value of technology utilized in this program to staff, and by extension, to students is that we had a means of introducing a dynamic element into the program through creating and accessing a range of podcasts and other digital learning objects. These materials were readily accessible to others through the server and informed the discussion in the online tutorials through Elluminate. The culture of shared learning was increasingly apparent, as this server, which supported blogs and multimedia and was available to all staff and students, became the repository for stimulating, dynamic, controversial and informative material. For example, students began to regularly upload self-generated podcasts, YouTube clips and other recordings that were elements of current educational debates, particularly when the staff running online tutorials made explicit that they welcomed such contributions.

The course structure enabled core material to be presented through a range of appropriate modalities, including face to face lectures and workshops, readings and reflections associated with core modules, reflection and evaluation of self and other during practicum, learning activities associated with assessment and feedback during participation and interaction with learning materials.

\section{Conclusion}

The challenge in seeking to maximize learning outcomes is to engage with the options that technologies present while considering both the specific and generic course learning outcomes. The addition of iPodassociated technology to the program through podcasting, the server and the iPod Touch improved student attitudes to trying new technology for future use in schools and provided flexible alternatives for accessing learning materials in an online environment. It provided a platform for creative sharing and collaboration and enabled student access to current material associated with the educational discourse. The project underpins and supports the notion that learning tools need to be considered as part of learning design which actively seeks to create communities of learners with a shared purpose of critically engaging in reflective discourse to achieve relevant learning through taking part in a functional Community of Inquiry (Garrison, 2011). The evidence of feedback from students to others on their experiences, both factual, technical and emotional are all evidence that the use of the mobile devices were able to foster a sense of belonging, a sense of worth to one another and a sense of shared commitment to each others' purposes that McMillan and Chavis (1986) identify as critical features of a sense of community.

\section{Acknowledgements}

We gratefully acknowledge the constructive feedback of our anonymous reviewers

\section{References}

Australasian Council on Open, Distance and E-learning. (2011). 2011 Australian Educational Technology Survey. ACODE, Australasian Council on Open, Distance and E-learning. Retrieved from http://www.csu.edu.au/division/landt/resources/documents/2011ed-techsurvey.pdf

Allen, I. E. \& Seaman, J. (2003). Sizing the opportunity: The quality and extent of online education in the United States, 2002 and 2003. Needham, MA: Sloan Consortium. Retrieved from http://www.sloanconsortium.org/resources/sizing_opportunity.pdf

Andrews, T., \& Tynan, B. (2012). Distance learners: Connected, mobile and resourceful individuals. Australasian Journal of Educational Technology, 28(4), 565-579. Retrieved from http://www.ascilite.org.au/aject28/andrews.html 
Beetham, H., \& Sharpe, R. (Eds.). (2007). Rethinking pedagogy for a digital Age. London: Routledge.

Biggs, J., \& Tang, C. (2009). Teaching for quality learning at university (2nd ed.). England: Open University Press.

Chan, A., Lee, M. J. W., \& McLoughlin, C. (2006). Everyone's learning with podcasting: A Charles Sturt University experience. In L. Markauskaite, P. Goodyear, \& P. Reiman (Eds.), Proceedings of the 23rd annual ascilite conference: Who's learning? Whose technology? (pp. 111-120). Sydney: Sydney University Press. Retrieved from http://www.ascilite.org.au/conferences/sydney06/proceeding/pdf_papers/vol2.pdf

Dale, C., \& Pymm, J. M. (2009). Podogogy: The iPod as a learning technology. Active Learning in Higher Education, 10(1), 84-96. doi:10.1177/1469787408100197

Draper, P. (2007). Students doing the driving: How undergraduates use ICT to enhance reflective practice, peer review and collaborative learning. Paper presented at the Music in Australian Tertiary Institutions - Issues for the 21st Century NACTMUS National Conference, Brisbane. Retrieved from http://www29.griffith.edu.au/imersd/draper/publications/research/200706\%20How\%20Undergraduates\%20use\%20ICT.pdf [viewed 14 January 2012].

Draper, P., \& Hitchcock, M. (2006, December). Podcasting: Can the eLearning experience inform eResearch in the digital arts? Paper presented at the CreateWorld 2006 conference and published on the conference website as an enhanced podcast, Griffith University, Brisbane. Retrieved from www29.griffith.edu.au/createworld

Edirisingha, P., Salmon, G., \& Fothergill, J. (2006). Profcasting: a pilot study and a model for integrating podcasts into online learning. Paper presented at the Fourth EDEN Research Workshop, Castelldefels, Spain. Retrieved from http:/www2.le.ac.uk/departments/beyond-distance-researchalliance/projects/impala1/presentations/Berlin/Pilot\%20study/view

Evans, C. (2008). The effectiveness of m-learning in the form of podcast revision lectures in higher education. Computers \& Education, 50(2), 491-498. Retrieved from http://dx.doi.org/10.1016/j.compedu.2007.09.016

Frydenberg, M. (2008). Principles and pedagogy: the two Ps of podcasting in the information technology classroom. Information Systems Education Journal, 6(6). Retrieved from http://isedj.org/6/6/

Garrison, D. R. (2011). E-learning in the 21st century: a framework for research and practice (2nd ed.). New York: Routledge.

Garrison, D. R., Anderson, T., \& Archer, W. (2000). Critical inquiry in a text-based environment: Computer conferencing in higher education. The Internet and Higher Education, 2(2-3), 87-105.

Garrison, D. R., \& Kanuka, H. (2004). Blended learning: Uncovering its transformative potential in higher education. The Internet and Higher Education, 7(2), 95-105.

Heilesen, S. B. (2010). What is the academic efficacy of podcasting? Computers \& Education, 55(3), 1063-1068. doi:10.1016/j.compedu.2010.05.002

King, K. P. (2002). Identifying success in online teacher education and professional development. The Internet and Higher Education, 5(3), 231-246.

Korthagen, F., Loughran, J., \& Russell, T. (2006). Developing fundamental principles for teacher education programs and practices. Teaching and Teacher Education, 22(8), 1020-1041. 
Lee, M. J.W., \& Chan, A. (2007a). Pervasive, lifestyle-integrated mobile learning for distance learners: an analysis and unexpected results from a podcast study. Open Learning: The Journal of Open and Distance Learning, 22(3), 201-218.

Lee, M. J.W., \& Chan, A. (2007b). Reducing the effects of isolation and promoting inclusivity for distance learners through podcasting. Turkish Online Journal of Distance Education-TOJDE, 8(1), 85-104.

Lonn, S., \& Teasley, S. (2009). Podcasting in higher education: What are the implications for teaching and learning? The Internet and Higher Education, 12(2), 88-92.

Madge, C., Meek, J., Wellens, J., \& Hooley, T. (2009). Facebook, social integration and informal learning at university: It is more for socializing and talking to friends about work than actually doing work. Learning, Media and Technology, 34(2), 141-155.

Mayes, T., \& de Freitas, S. (2007). Learning and e-learning: The role of theory. In H. Beetham \& R. Sharpe (Eds.), Rethinking pedagogy for the digital age (pp. 13-25). London: Routledge.

McGarr, O. (2009). A review of podcasting in higher education: Its influence on the traditional lecture. Australasian Journal of Educational Technology, 25(3), 309-321. Retrieved from http://ascilite.org.au/ajet/ajet25/mcgarr.pdf

McLoughlin, C., \& Lee, M. J. W. (2008). The three P's of pedagogy for the networked society: Personalisation, participation and productivity. International Journal of Teaching and Learning in Higher Education, 20(1), 10-27.

McMillan, D. W., \& Chavis, D. M. (1986). Sense of community: A definition and theory. Journal of Community Psychology, 14(1), 6-23.

Oliver, R. (1999). Exploring strategies for online teaching and learning. Distance Education, 20(2), 240254.

Ragusa, A. T., Chan, A., \& Crampton, A. (2009). iPods aren't just for tunes: exploring podcasting as a socio-cultural technology facilitating student experiences of higher education in rural Australia. Information, Communication \& Society, 12(5), 678-690. Retrieved from http://libezproxy.open.ac.uk/login?url=http://search.ebscohost.com.libezproxy.open.ac.uk/login.aspx? direct $=$ true $\& \mathrm{db}=\mathrm{ufh} \& \mathrm{AN}=43744012 \&$ site $=$ eds-live $\&$ scope $=$ site

Rovai, A. (2002). Building sense of community at a distance. International Review of Research in Open and Distance Learning, 3(1), 1-16. Retrieved from http://www.icaap.org/iuicode?149.3.1.x

Salmon, G., \& Edirisingha, P. (Eds.). (2008). Podcasting for learning in universities. England: Open University Press.

Selwyn, N. (2009) Faceworking: exploring students' education-related use of Facebook. Learning, Media and Technology, 34(2), 157-174

Stephenson, J. (Ed.). (2001). Teaching and learning online pedagogies for the new technologies. London: Kogan Page.

Tynan, B., \& Colbran, S. (2006). Podcasting, student learning and expectations. In L. Markauskaite, P. Goodyear, \& P. Reiman (Eds.), Proceedings of the 23rd annual ascilite conference: Who's learning? Whose technology? (pp. 825-832). Sydney: Sydney University Press. Retrieved from http://www.ascilite.org.au/conferences/sydney06/proceeding/pdf_papers/vol2.pdf 
Corresponding author: Caroline Walta, c.walta@latrobe.edu.au

Australasian Journal of Educational Technology (C) 2013.

Please cite as: Walta, C., \& Nicholas, H. (2013). The iPod Touch in association with other technologies in support of a community of inquiry in off-campus teacher education. Australasian Journal of Educational Technology, 29(6), 870-886. 